Article

\title{
Ammonia, Hydrogen Sulfide, and Greenhouse Gas Emissions from Lab-Scaled Manure Bedpacks with and without Aluminum Sulfate Additions
}

\author{
Mindy J. Spiehs ${ }^{1, *}$, Bryan L. Woodbury ${ }^{1}$ and David B. Parker ${ }^{2}$ \\ 1 USDA Agricultural Research Service, Meat Animal Research Center, Spur 18D, Clay Center, NE 68933, USA; \\ bryan.woodbury@usda.gov \\ 2 USDA Agricultural Research Service, Conservations and Production Research Laboratory, \\ Bushland, TX 79012, USA; david.parker@usda.gov \\ * Correspondence: mindy.spiehs@usda.gov
}

Received: 26 July 2019; Accepted: 18 September 2019; Published: 20 September 2019

check for updates

\begin{abstract}
The poultry industry has successfully used aluminum sulfate (alum) as a litter amendment to reduce $\mathrm{NH}_{3}$ emissions from poultry barns, but alum has not been evaluated for similar uses in cattle facilities. A study was conducted to measure ammonia $\left(\mathrm{NH}_{3}\right)$, greenhouse gases (GHG), and hydrogen sulfide $\left(\mathrm{H}_{2} \mathrm{~S}\right)$ emissions from lab-scaled bedded manure packs over a 42-day period. Two frequencies of application (once or weekly) and four concentrations of alum (0, 2.5, 5, and 10\% by mass) were evaluated. Frequency of alum application was either the entire treatment of alum applied on Day 0 (once) or $16.6 \%$ of the total alum mass applied each week for six weeks. Ammonia emissions were reduced when $10 \%$ alum was used, but $\mathrm{H}_{2} \mathrm{~S}$ emissions increased as the concentration of alum increased in the bedded packs. Nitrous oxide emissions were not affected by alum treatment. Methane emissions increased as the concentration of alum increased in the bedded packs. Carbon dioxide emissions were highest when $5 \%$ alum was applied and lowest when $0 \%$ alum was used. Results of this study indicate that $10 \%$ alum is needed to effectively reduce $\mathrm{NH}_{3}$ emissions, but $\mathrm{H}_{2} \mathrm{~S}$ and methane emissions may increase when this concentration of alum is used.
\end{abstract}

Keywords: ammonia; beef; bedding; carbon dioxide; greenhouse gas; hydrogen sulfide; methane; nitrous oxide

\section{Introduction}

Ammonia $\left(\mathrm{NH}_{3}\right)$ is one of many common by-products of livestock production. The nitrogen $(\mathrm{N})$ content in animal feeds is often fed in excess of the animals' nutrient requirements, resulting in surplus $\mathrm{N}$ that is excreted in the urine and feces of the animal. Stowell reported that only an estimated $10-30 \%$ of $\mathrm{N}$ that is consumed by cattle is utilized by the animal for growth, reproduction, milk production, and maintenance needs, with the remainder being excreted [1]. Nitrogen is an essential nutrient for plants, and the $\mathrm{N}$ retained in animal waste or on the feedlot surface can be used to fertilize cropland. Unfortunately, $\mathrm{N}$ losses as $\mathrm{NH}_{3}$ from beef cattle feedlots can be quite high. Research conducted at Texas feedlots found $68 \% \mathrm{~N}$ loss as $\mathrm{NH}_{3}$ in summer and $36 \%$ during winter months [2]. Similar research conducted in Nebraska feedlots found $51-63 \% \mathrm{~N}$ loss as $\mathrm{NH}_{3}$ during summer months and $35-41 \%$ during winter months [3-5]. Nitrogen is primarily excreted through urine, with upward of $97 \%$ of urinary $\mathrm{N}$ in the form of urea [6,7]. When urine and feces are exposed to each other, the urea in urine is rapidly converted to $\mathrm{NH}_{3}$ via the enzyme urease, which is found in feces [8]. This reaction is modulated by $\mathrm{pH}$ and temperature, with greater volatilization during the summer months compared to winter months [3-5]. The ideal $\mathrm{pH}$ for $\mathrm{NH}_{3}$ volatilization is 7 to 10 [9], whereas $\mathrm{pH} \leq 6.5$ will result in little $\mathrm{NH}_{3}$ volatilization [10]. This is a function of the $\mathrm{pKa}$, with ammonium $\left(\mathrm{NH}_{4}\right)$ being less volatile 
than $\mathrm{NH}_{3}$. Consequently, amendments that lower the $\mathrm{pH}$ of the beef feedlot surface material may reduce $\mathrm{N}$ volatilization and retain $\mathrm{N}$ in the manure to be used for fertilizer. This would be especially beneficial during the warm summer months.

Aluminum sulfate (alum) has been used successfully in the poultry industry to lower $\mathrm{NH}_{3}$ emissions for the past decade [11,12]. Alum lowers the $\mathrm{pH}$ of the litter to bind $\mathrm{N}$ as $\mathrm{NH}_{4}$ and prevent volatilization. The typical application rate is $5-10 \%$ of the weight of the litter [13-15]. Ammonia fluxes from alum-treated litter have been reported to be $70 \%$ lower than untreated litter [11]. Litter treated with alum also has a higher $\mathrm{N}$ content than untreated litter, which increases the fertilizer value of the litter [12]. Phosphorus (P) leaching is also reduced when the litter is land applied, due to a lower soluble $\mathrm{P}$ content in the alum-treated litter compared to untreated litter. We hypothesized that $\mathrm{NH}_{3}$ volatilization would be lower from a manure and bedding mixture treated with alum compared to an untreated mixture of manure and bedding. However, we were unsure if alum would affect greenhouse gas and hydrogen sulfide $\left(\mathrm{H}_{2} \mathrm{~S}\right)$ volatilization from the bedpacks treated with alum.

\section{Materials and Methods}

A two $\times$ four factorial study with repeated measures over time was conducted to examine the effects of alum addition on gas emissions from manure bedded packs. Two dose frequencies (once or weekly) and four concentrations of alum $(0,2.5,5$, or $10 \%$ alum by mass) were examined. Thirty-two laboratory-scaled simulated bedded packs were constructed and maintained for 42 days, as previously described [16-21]. The study was conducted twice (Period 1 and Period 2) for a total of 64 experimental units. Briefly, bedded packs were constructed using plastic containers that were $0.5 \mathrm{~m}$ high and had a diameter of $0.38 \mathrm{~m}$. Each container had six $1 \mathrm{~cm}$ holes equally spaced around the circumference of the container, approximately $5 \mathrm{~cm}$ from the top of the container, to serve as air inlets [21]. Corn stover was used as the bedding material. Three times per week, urine and feces were added to the bedded packs. The bedded packs were stirred slightly at each addition to represent hoof action on the bedded packs. The bedded packs were housed in four environmental chambers [22] that were maintained at an ambient temperature of $18{ }^{\circ} \mathrm{C}$ with a dew point of $12{ }^{\circ} \mathrm{C}$ throughout the study. This temperature and dew point were selected to represent conditions during a moderate season in a barn [23], like spring or fall, and have been used in previous studies [16-21]. There were eight bedded packs per chamber.

Once weekly, air samples were collected for 18 minutes per bedded pack using dynamic flux chambers. The flux chambers were stainless steel hemispherical flux chambers that were $7 \mathrm{~L}$ with a surface area of $640 \mathrm{~cm}^{2}[24,25]$. Inside the headspace of the chamber was a $40 \mathrm{~mm}, 12 \mathrm{~V}$ axial-flow fan moving approximately $130 \mathrm{~L} \mathrm{~min}^{-1}$. The fan was suspended in the center of the headspace approximately $70 \mathrm{~mm}$ above the bedded pack surface. The fan airflow direction was from the surface to the top of the chamber. Rubber skirts that were $61 \mathrm{~cm}$ square and made of soft, elastic rubber with $22.9 \mathrm{~cm}$ diameter holes cut in the center were fit over each flux chamber to form a seal on the top of the plastic container when the flux chamber was placed on the plastic container for air sampling [21]. A $0.64 \mathrm{~cm}$ inert tubing was attached to the flux chambers using inert compression fittings [21]. The inert tubing was attached to the gas sampling manifold that fed into the air sampling equipment [21]. The gas sampling system was controlled by a 24 V Programmable Logic Relay, which signaled multi-positional three-way solenoids to open and close one of eight air inlet lines on the gas sampling manifold [21]. One line was opened at a time to allow for individual air sampling from each bedded pack [21]. Ambient air from the room was flushed through the tubing at a rate of $5 \mathrm{~L} \mathrm{~min}^{-1}$ for $30 \mathrm{~min}$ [21]. After the $30 \mathrm{~min}$ flush period, sampling was conducted for 18 minutes per bedded pack. Air samples were analyzed for $\mathrm{H}_{2} \mathrm{~S}$ using a Thermo Fisher 450i Hydrogen Sulfide/Sulfur Dioxide/Combined Sulfur Pulsed Fluorence gas analyzer (Thermo Fisher Scientist, Waltham, MA, USA). A Thermo Fisher 17i Ammonia Chemiluminescent gas analyzer was used to measure $\mathrm{NH}_{3}$ (Thermo Fisher Scientist, Waltham, MA, USA). Methane was measured using a Thermo Fisher 55i Direct Methane and Non-methane Hydrocarbon Backflush Gas Chromatograph gas analyzer (Thermo 
Fisher Scientific, Waltham, MA, USA). Nitrous oxide $\left(\mathrm{N}_{2} \mathrm{O}\right)$ and carbon dioxide $\left(\mathrm{CO}_{2}\right)$ were measured using an Innova 1412 Photoacoustic gas monitor (LumaSense Technologies, Santa Clara, CA, USA).

The temperature and $\mathrm{pH}$ of each bedded pack were measured at each sampling date. A grab sample of approximately 10-15 g was collected from each bedded pack and placed in a $50 \mathrm{~mL}$ plastic conical. Samples were diluted 1:2 on a mass basis with distilled water. A pH/mV/temperature meter (IQ150, Spectrum Technologies, Inc., Plainsfield, IL, USA), calibrated with buffers $\mathrm{pH} 4$ and 7, was then used to determine $\mathrm{pH}$. Pack temperature was measured approximately $7.6 \mathrm{~cm}$ below the surface of the simulated bedded pack using the same meter. At the beginning and end of the study, a sample of each simulated bedded pack was collected and analyzed for dry matter (DM), total N, total phosphorus (P), total potassium (K), and total sulfur (S). Dry matter was determined by weighing samples before and after drying at $100{ }^{\circ} \mathrm{C}$ in a forced-air oven for $24 \mathrm{~h}$. Samples collected from the simulated bedded packs were dried, ground through a $1 \mathrm{~mm}$ screen, and sent to a commercial laboratory (Ward Laboratory, Inc., Kearney, NE) for N [26], P, S [27] analysis.

Treatments were applied on Day 0 and measurements were recorded once weekly for the following six weeks (Day 42). The treatments included 0, 2.5, 5, and 10\% alum applied as either a whole treatment on Day 0 or $16.6 \%$ of the total alum volume applied each week for six weeks. The quantity of alum added was based on the expected total mass of the bedded packs at the end of the 42-day study. Treatments were selected based on previous research in the poultry industry, which indicated $5-10 \%$ alum by mass was adequate to reduce $\mathrm{NH}_{3}$ volatilization [13-15]. As reported by Moore and co-workers [13], a series of studies has consistently demonstrated that $\mathrm{pH}$ begins to rise and $\mathrm{NH}_{3}$ emissions begin to increase about four weeks post application when used in poultry facilities. This study was designed to slightly exceed that four-week threshold, to determine the maximum length of time $\mathrm{NH}_{3}$ emissions could be suppressed from cattle bedded packs.

For all measurements, Day 0 samples were collected prior to any urine, feces, or alum being added to the bedding material. The reason for doing this was to determine baseline emissions from the corn stover bedding independently of urine, feces, or alum. Previous studies with alum had all been conducted in poultry barns that use wood-based bedding material. We wanted to make sure that corn stover alone was not contributing to high gaseous emissions. In most cases, these measurements were essentially zero.

Data were analyzed as a $4 \times 2$ factorial with repeated measures in time using the MIXED procedure of SAS (SAS Institute, Cary, NC, USA). The model included the effects of period, alum concentration, dose frequency, day, and all interactions. Covariate structure was modeled to get lowest Akaike information criteria (AIC) value. Several structures were tested and the compound symmetry covariate structure provided the lowest AIC value. When significant differences were detected, the least square means were calculated using Fisher's least significant differences. The nutrient data was analyzed as a $4 \times 2$ factorial using the MIXED procedure of SAS (SAS Institute, Cary, NC, USA) to test the effects of alum concentration, dose frequency, and the interaction of the two variables. Bedded pack was the experimental unit in all analyses, and differences were considered significant when $p<0.05$.

\section{Results and Discussion}

\subsection{Temperature and $p H$}

The temperature of the bedded packs ranged from 19.1 to $21.7^{\circ} \mathrm{C}$ and did not differ amongst bedding packs at any point during the 42 -day study (Table 1 ). These temperatures were within the range of previous studies using a similar lab-scaled design $[16,20]$, but less than pack temperatures measured by Ayadi [28] when using environmental chambers set at $40^{\circ} \mathrm{C}$. The average temperature of the bedded pack in four commercial facilities was $25.7^{\circ} \mathrm{C}$ but ranged from 15 to $29^{\circ} \mathrm{C}$ depending on the season [23]. Although no lab-scale system can perfectly simulate the environment in a commercial facility, the lab-scale simulated bedded packs have consistently produced physical characteristics within the ranges measured in commercial facilities and allow researchers a small-scaled tool that can be used for initial evaluation of multiple treatments. 
Table 1. Mean $\mathrm{pH}$ and temperature $\left({ }^{\circ} \mathrm{C}\right)$ of bedded pack material on Day $0-42$ following the addition of alum.

\begin{tabular}{|c|c|c|c|c|c|c|c|c|}
\hline \multicolumn{9}{|c|}{$\mathrm{pH}$} \\
\hline \multirow{2}{*}{ Dose Frequency } & \multirow{2}{*}{ Alum } & \multicolumn{7}{|c|}{ Day } \\
\hline & & 0 & 7 & 14 & 21 & 28 & 35 & 42 \\
\hline Once & $0 \%$ & 7.06 & $8.49^{a}$ & $8.18^{a}$ & $8.03^{a}$ & $7.97^{\mathrm{a}}$ & $7.81^{\mathrm{a}}$ & $7.79^{b}$ \\
\hline Weekly & $0 \%$ & 7.04 & $8.51^{a}$ & $8.27^{\mathrm{a}}$ & $8.10^{\mathrm{a}}$ & $7.76^{a, b}$ & $7.91^{a}$ & $7.82^{b}$ \\
\hline Once & $2.5 \%$ & 7.05 & $8.43^{a, b}$ & $8.16^{a, b}$ & $8.14^{\mathrm{a}}$ & $7.84^{\mathrm{a}, \mathrm{b}}$ & $7.98^{a}$ & $7.96^{\mathrm{a}}$ \\
\hline Weekly & $2.5 \%$ & 6.95 & $8.44^{\mathrm{a}}$ & $8.19^{a}$ & $8.04^{\mathrm{a}}$ & $7.77^{a, b}$ & $7.85^{a}$ & $7.66^{b, c}$ \\
\hline Once & $5 \%$ & 7.00 & $8.03^{c}$ & $8.14^{\mathrm{a}}$ & $8.00^{\mathrm{a}}$ & $7.75^{a, b}$ & $7.85^{\mathrm{a}}$ & $7.77^{b}$ \\
\hline Weekly & $5 \%$ & 7.20 & $8.29^{a, b}$ & $8.08^{a, b}$ & $8.03^{a}$ & $7.75^{a, b}$ & $7.83^{a}$ & $7.83^{b}$ \\
\hline Once & $10 \%$ & 7.00 & $6.92^{\mathrm{d}}$ & $7.93^{\mathrm{b}}$ & $7.97^{a, b}$ & $7.68^{b}$ & $7.84^{\mathrm{a}}$ & $7.70^{b, c}$ \\
\hline Weekly & $10 \%$ & 7.17 & $8.21^{a, b}$ & $8.17^{a, b}$ & $7.62^{b}$ & $7.64^{b}$ & $7.65^{b}$ & $7.60^{c}$ \\
\hline \multicolumn{9}{|c|}{ Temperature } \\
\hline \multirow{2}{*}{ Dose Frequency } & \multirow{2}{*}{ Alum } & \multicolumn{7}{|c|}{ Day } \\
\hline & & 0 & 7 & 14 & 21 & 28 & 35 & 42 \\
\hline Once & $0 \%$ & 20.0 & 19.1 & 20.2 & 21.2 & 21.7 & 21.1 & 21.6 \\
\hline Weekly & $0 \%$ & 20.0 & 19.1 & 20.0 & 21.4 & 21.3 & 21.1 & 21.6 \\
\hline Once & $2.5 \%$ & 20.0 & 19.1 & 20.0 & 21.3 & 21.4 & 20.9 & 21.6 \\
\hline Weekly & $2.5 \%$ & 20.0 & 19.2 & 20.1 & 21.1 & 21.4 & 20.9 & 21.6 \\
\hline Once & $5 \%$ & 20.0 & 19.1 & 19.9 & 21.0 & 21.1 & 20.9 & 21.5 \\
\hline Weekly & $5 \%$ & 20.0 & 19.2 & 19.7 & 21.1 & 21.1 & 20.7 & 21.5 \\
\hline Once & $10 \%$ & 20.0 & 19.3 & 20.0 & 21.0 & 21.1 & 20.8 & 21.7 \\
\hline Weekly & $10 \%$ & 20.0 & 19.4 & 20.4 & 21.2 & 21.4 & 21.1 & 21.7 \\
\hline
\end{tabular}

The $\mathrm{pH}$ of the bedded packs was also within the range of previous lab-scaled studies (6.2 to 9.0; $[16,20,28])$ and data collected from commercial facilities (7.5-8.0; [23]). Previous studies using $10 \%$ alum in poultry litter reported a litter $\mathrm{pH}$ ranging from approximately 7.5 to 8.0 in untreated litter to approximately 5.75 immediately after a $10 \%$ alum treatment [13]. The $\mathrm{pH}$ began to gradually increase and reached approximately 7.5 four weeks after application [13]. In the current study, the $\mathrm{pH}$ of the untreated bedded packs was similar to untreated litter, but $10 \%$ alum was able to lower the $\mathrm{pH}$ of poultry litter to 5.75 , while the $10 \%$ treatment applied in one dose only lowered the $\mathrm{pH}$ of the bedded pack to 6.92. Further studies will be warranted to determine if a higher dosage of alum may be necessary to sufficiently lower $\mathrm{pH}$. As expected, the $\mathrm{pH}$ of the bedded packs changed when alum was added. Initial measurements from the bedded pack taken on Day 0 were collected immediately before adding the alum and did not show any significant differences between the treatments. On Day 7 , the $\mathrm{pH}$ of the bedded packs that received the $10 \%$ alum treatment in one dose was lower $(p<0.01)$ than the $\mathrm{pH}$ of bedded packs that received all other treatments. The bedded packs that received the $5 \%$ alum treatment in one dose had the second lowest $\mathrm{pH}$, followed by the $10 \%$ weekly treatment, $5 \%$ weekly treatment, and $2.5 \%$ dose administered at once. Expectedly, the largest concentration of alum administered in one dose was the most effective in lowering the initial $\mathrm{pH}$. This low $\mathrm{pH}$ was sustained through Day 14, but by Day 21, only the bedded packs receiving the $10 \%$ weekly alum treatment maintained a lower $\mathrm{pH}$. Alum applied to poultry litter prior to a six-week grow-out was particularly effective at lowering $\mathrm{pH}$ during the first three to four weeks [11]. Therefore, it was not surprising that the alum would begin to lose efficacy around Day 21.

Beginning on Day 28, an overall decrease in $\mathrm{pH}$ of all bedded packs was observed, with the bedded packs containing the $10 \%$ alum treatment having significantly lower $\mathrm{pH}$ than those that did not receive alum. This decrease in bedded pack $\mathrm{pH}$ has been observed in previous studies using this experimental design, although the decrease did not happen until Day 35 in previous studies $[17,19]$. It is likely caused by an increase in volatile fatty acid (VFA) production as the manure mixture ages, as demonstrated by other researchers $[16,29,30]$. On Day 35, only the bedded packs receiving the $10 \%$ 
alum weekly dose had a significantly lower $\mathrm{pH}$. At the end of the study, the bedded packs with the $10 \%$ weekly alum treatment had the lowest $\mathrm{pH}$, which did not differ statistically from the $\mathrm{pH}$ of the bedded packs receiving the $10 \%$ once treatment and the $2.5 \%$ weekly treatment, with all other bedded packs having a higher $\mathrm{pH}$. It is unclear why the bedded pack with the $2.5 \%$ weekly treatment had such a significant drop in $\mathrm{pH}$ between Day 35 and Day 42.

\subsection{Ammonia}

Ammonia flux was significantly lower for bedded packs that received the $10 \%$ treatment in one dose compared to any other treatment at Day 7 (Figure 1). The bedded packs that received $2.5 \%$ alum had significantly higher $\mathrm{NH}_{3}$ flux than those with $10 \%$ alum administered in one dose, but significantly lower than all other treatments on Day 7. At Day 14, the $\mathrm{NH}_{3}$ fluxes from bedded packs that received both $10 \%$ alum treatments were not different from one another, but were significantly lower than other treatments, with those receiving the $2.5 \%$ and $5 \%$ alum in one dose having significantly higher $\mathrm{NH}_{3}$ fluxes than the $10 \%$ treatments, but significantly lower $\mathrm{NH}_{3}$ fluxes than the other treatments. From Day 21 until the end of the study, only the bedded packs with the $10 \%$ alum administered in weekly doses consistently maintained a significantly lower $\mathrm{NH}_{3}$ flux than the bedded packs that were not treated with alum.

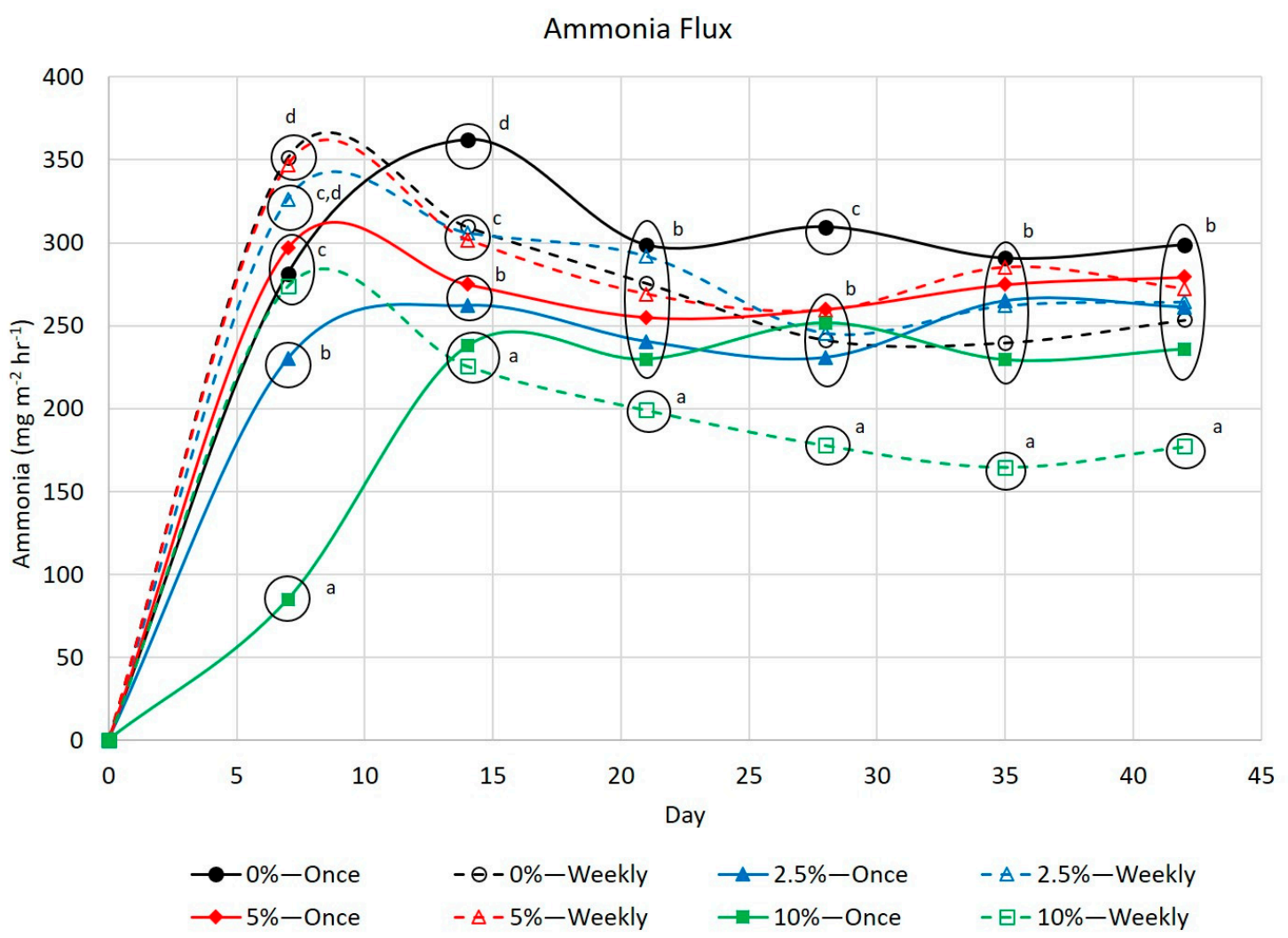

Figure 1. Average ammonia flux $\left(\mathrm{mg} \mathrm{m}^{-2} \mathrm{~h}^{-1}\right)$ for weekly measurements taken over 42 days for bedded packs treated with $0,2.5,5$, and $10 \%$ alum, either in one dose or in weekly doses. Alum $\times$ Dose $\times$ Day interaction $p<0.01$, Pooled standard error of the mean $=8.19$. Clusters with different letters indicate significant differences $p<0.05$.

Ammonia flux followed the pack $\mathrm{pH}$. On Day 7, the bedded packs that received the single dose of $10 \%$ alum had statistically lower $\mathrm{NH}_{3}$ emission than all other bedded packs (Figure 1). This corresponded to the low Day $7 \mathrm{pH}$ for the bedded pack that received a single dose of $10 \%$ alum. At Day 14 , the $\mathrm{pH}$ of both $10 \%$ alum treatments, the $2.5 \%$ alum treatment that was administered once, and the $5 \%$ alum treatment that was administered once had the lowest $\mathrm{pH}$ values. The $\mathrm{NH}_{3}$ emissions from 
these four treatments were also lowest on Day 14. By Day 21 and throughout the remainder of the study, the pHs of the bedded packs that were administered a weekly dose of $10 \%$ alum were lowest, which corresponded to the low $\mathrm{NH}_{3}$ emissions for bedded packs that received weekly doses with the $10 \%$ alum concentration. Bedded packs that received weekly allotments of the $10 \%$ alum treatment had $73 \%$ of the $\mathrm{NH}_{3}$ emissions of the bedded packs that did not receive an alum treatment.

\subsection{Greenhouse Gases}

There was a significant alum concentration $\times$ dose frequency $\times$ day effect for $\mathrm{CO}_{2}$ flux (Figure 2). However, in general, the $\mathrm{CO}_{2}$ flux from bedded packs receiving the $5 \%$ alum dose, regardless of whether it was administered weekly or in one dose, had the highest $\mathrm{CO}_{2}$ flux, with the bedded packs that received no alum having the lowest $\mathrm{CO}_{2}$ flux. It is unclear why the bedded packs receiving the $5 \%$ alum treatments produced the highest $\mathrm{CO}_{2}$ flux. A reduction in $\mathrm{pH}$ could affect the concentration of gases near the surface of the bedded pack and would favor the emission of weak acid forming gases, such as $\mathrm{CO}_{2}$ [31]. However, if the increase in $\mathrm{CO}_{2}$ was purely $\mathrm{pH}$-dependent, it would be expected that the bedded packs receiving the $10 \%$ alum treatment would have the highest $\mathrm{CO}_{2}$ emission, not the bedded packs receiving the $5 \%$ alum treatments. The carbon dioxide flux of the bedded packs receiving the $10 \%$ alum in weekly allotments was $104 \%$ that of the untreated bedded packs, but did not differ statistically. Over the course of the 42-day experiment, the $\mathrm{CO}_{2}$ flux increased for all bedded packs, regardless of treatments. This gradual increase in $\mathrm{CO}_{2}$ flux is consistent with previous studies $[17,19,28]$. Carbon dioxide is produced during aerobic respiration and indicates biological activity in the bedded packs. As the packs matured, the decomposition of feces and bedding material began, which likely contributed to the increase in $\mathrm{CO}_{2}$ emissions as the packs aged.

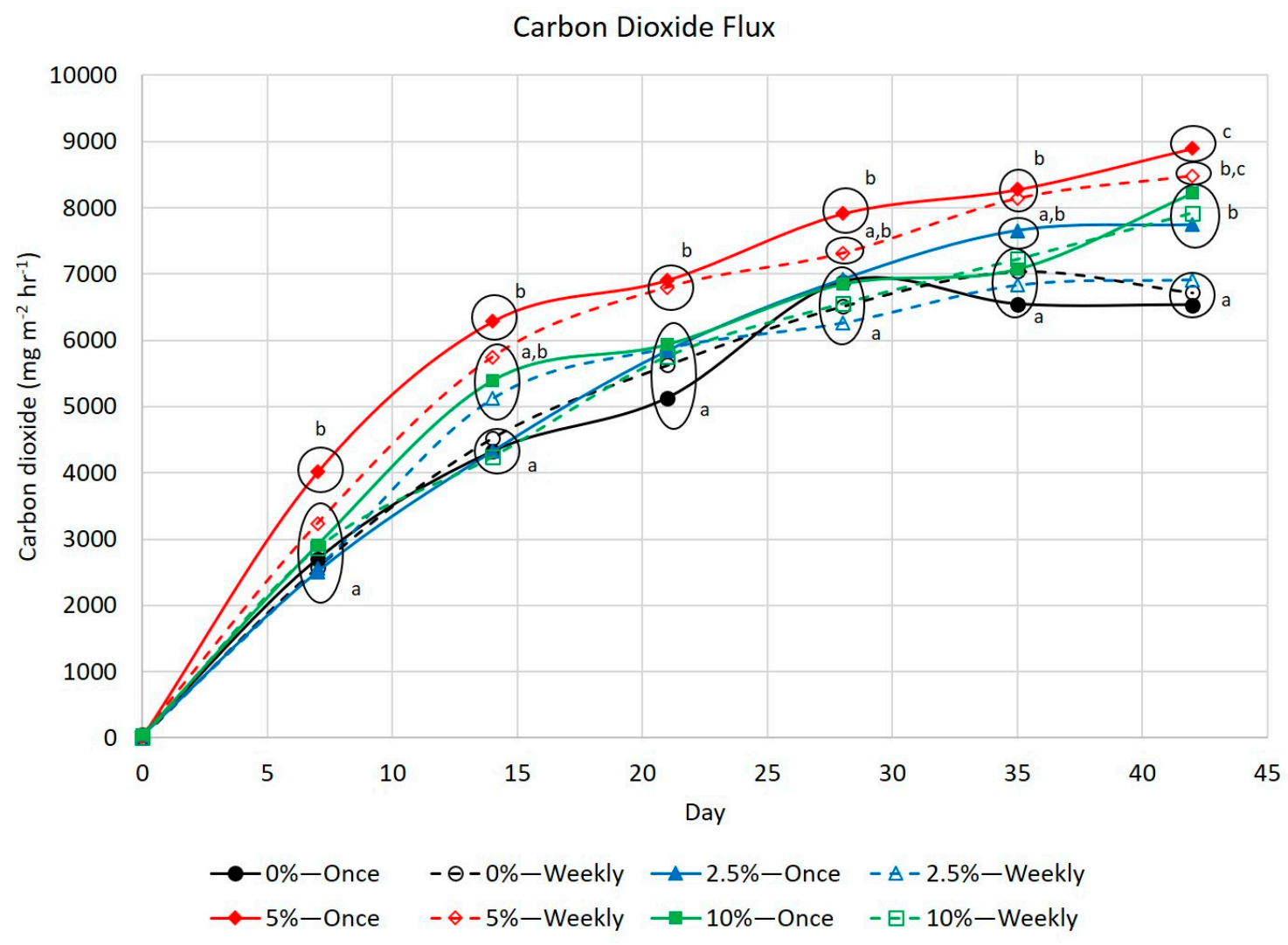

Figure 2. Average carbon dioxide flux $\left(\mathrm{mg} \mathrm{m}^{-2} \mathrm{~h}^{-1}\right)$ for weekly measurements taken over 42 days for bedded packs treated with $0,2.5,5$, and $10 \%$ alum, either in one dose or in weekly doses. Alum $\times$ Dose $\times$ Day interaction $p<0.01$, Pooled standard error of the mean $=154.3$. Clusters with different letters indicate significant differences $p<0.05$. 
Methane is produced during anaerobic decomposition of organic matter [32-35]. Methaneproducing bacteria can survive in temperatures ranging from 15 to $60^{\circ} \mathrm{C}$, with an ideal temperature of $35-37^{\circ} \mathrm{C}$ [36]. An ideal $\mathrm{pH}$ is between 6.7 and 7.5 [37,38]. Methane production was largely nonexistent until Day 21 of the study (Figure 3), which is consistent with previous studies conducted using simulated bedded packs $[17,19]$. While ideal conditions for $\mathrm{CH}_{4}$ production were never achieved during this study, the weekly increases in bedded pack height as urine, feces, and bedding were added each week can be assumed to have made a more anaerobic environment towards the bottom of the bedded packs as the study progressed. Beginning at Day 28 , the bedded packs that received the $10 \%$ alum treatments had the greatest $\mathrm{CH}_{4}$ production, followed by those receiving both $5 \%$ alum treatments. This was likely due to the fact that the $\mathrm{pH}$ of the bedded packs containing $10 \%$ alum maintained a $\mathrm{pH}$ of 7.62-7.97 compared to higher $\mathrm{pH}$ values for the bedded packs that received all other treatments, particularly on Day 28 , when $\mathrm{CH}_{4}$ production peaked. The lower $\mathrm{pH}$, while not ideal for methanogens, is certainly more conducive to the production of $\mathrm{CH}_{4}$. For each concentration of alum applied to bedded packs, peak $\mathrm{CH}_{4}$ production was significantly greater when the alum was applied in weekly allotments compared to one dose. Methane fluxes from the bedded packs that received the weekly dose of $10 \%$ alum were $274 \%$ of the flux from bedded packs that were not treated with alum. Methane production peaked at Day 28 and began to decline by Day 35 .

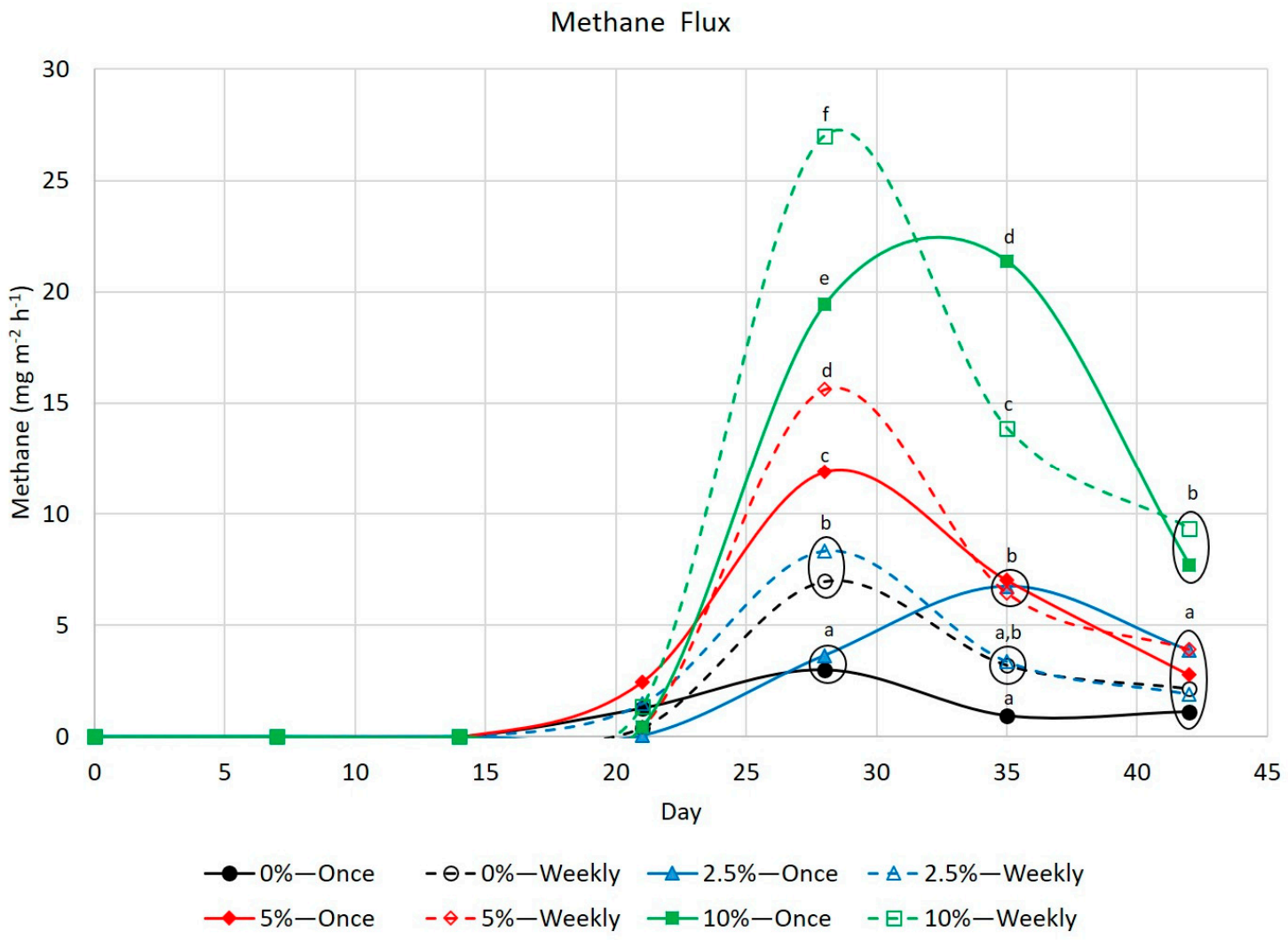

Figure 3. Average methane flux $\left(\mathrm{mg} \mathrm{m}^{-2} \mathrm{~h}^{-1}\right)$ for weekly measurements taken over 42 days for bedded packs treated with $0,2.5,5$, and $10 \%$ alum, either in one dose or in weekly doses. Alum $\times$ Dose $\times$ Day interaction $p<0.01$, Pooled standard error of the mean $=0.76$. Clusters with different letters indicate significant differences $p<0.05$.

Nitrous oxide emissions from livestock facilities are of increasing concern for producers due to the global warming potential of $\mathrm{N}_{2} \mathrm{O}$ being 296 times greater than that of $\mathrm{CO}_{2}$ [39]. Nitrous oxide concentrations ranged from 0.01 to $0.69 \mathrm{mg} \mathrm{m}^{-2} \mathrm{~h}^{-1}$ and were highly variable across treatments throughout the study (Figure 4), which was similar to previous studies [17,19]. This variability over time may be attributed to the micro-environments on the surface of the bedded packs being disrupted 
with periodic stirring of the pack. When the pack is stirred, the anaerobic layer is disrupted and nitrifying and denitrifying processes may be altered as a result. Two peaks appeared, at Day 7 and Day 21, which is slightly different from previous studies, which had peaks at Day 14 and Day 42 [17-19]. At Day 7 , bedded packs that received the $5 \%$ alum in one dose had significantly higher $\mathrm{N}_{2} \mathrm{O}$ emissions and those that received the $10 \%$ weekly dose had significantly lower $\mathrm{N}_{2} \mathrm{O}$ emissions, with all other treatments being similar. During the Day 21 peak, bedded packs that received the $2.5 \%$ weekly alum and $0 \%$ weekly dose had the highest $\mathrm{N}_{2} \mathrm{O}$ emissions, with those receiving the $10 \%$ weekly dose once again having lower emissions. Overall, for the 42-day study, bedded packs treated with the $10 \%$ alum weekly treatment had lower $\mathrm{N}_{2} \mathrm{O}$ emissions (Figure 5). Those given either $0 \%$ alum treatment, the $2.5 \%$ treatment in weekly increments, or the $5 \%$ alum in one dose had the highest $\mathrm{N}_{2} \mathrm{O}$ loss, with the packs receiving the $10 \%$ alum treatment in one dose, the $5 \%$ alum treatment in weekly increments, and $2.5 \%$ alum treatment in one dose had intermediate $\mathrm{N}_{2} \mathrm{O}$ emissions. Treating the bedded packs with weekly doses of $10 \%$ alum resulted in a flux $64 \%$ of that for the untreated bedded packs.

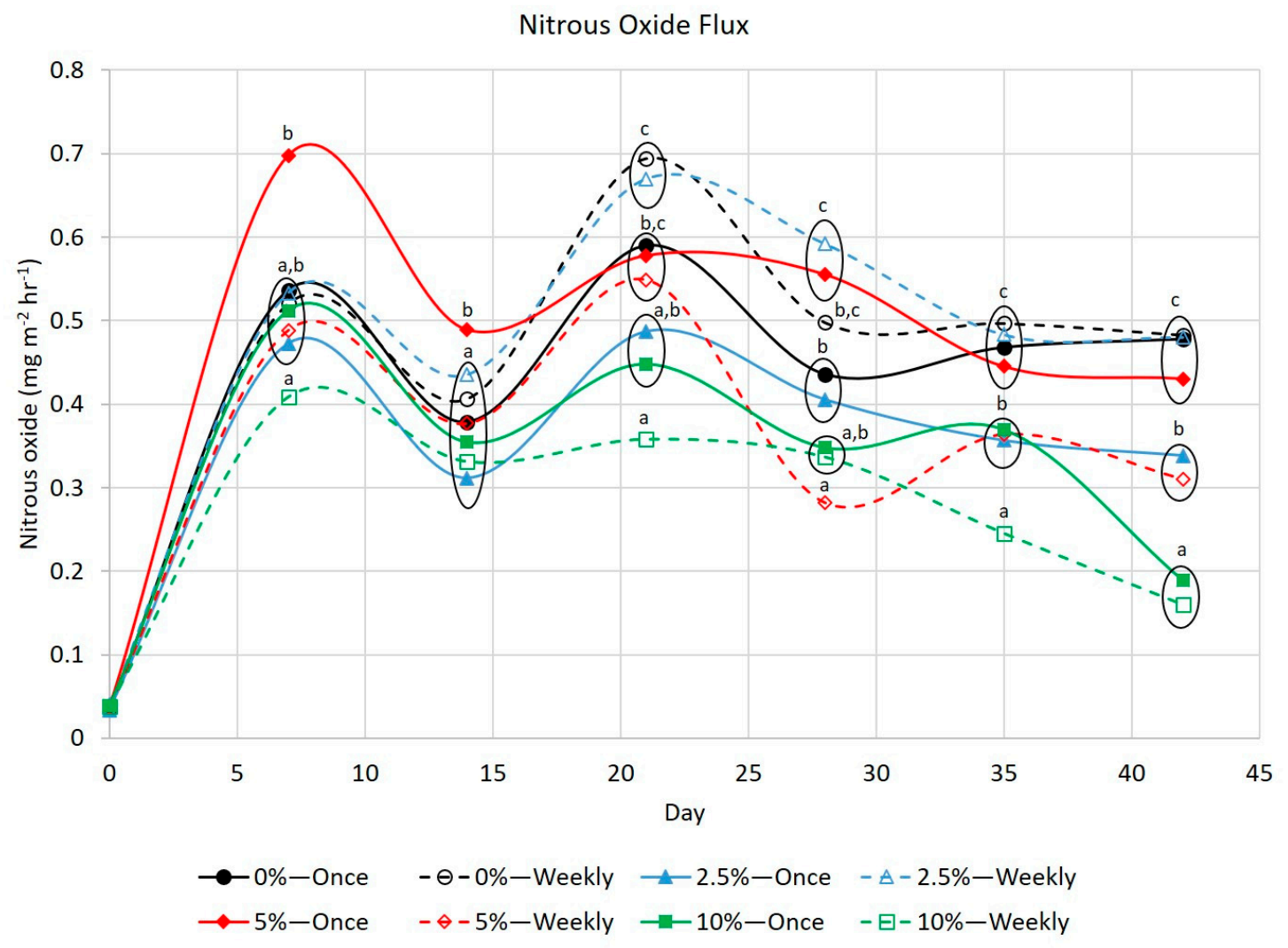

Figure 4. Average nitrous oxide flux $\left(\mathrm{mg} \mathrm{m}^{-2} \mathrm{~h}^{-1}\right)$ for weekly measurements taken over 42 days for bedded packs treated with $0,2.5,5$, and $10 \%$ alum either in one dose or in weekly doses. Alum $\times$ Dose $\times$ Day interaction $p<0.01$, pooled standard error of the mean $=0.05$. Clusters with different letters indicate significant differences $p<0.05$. 


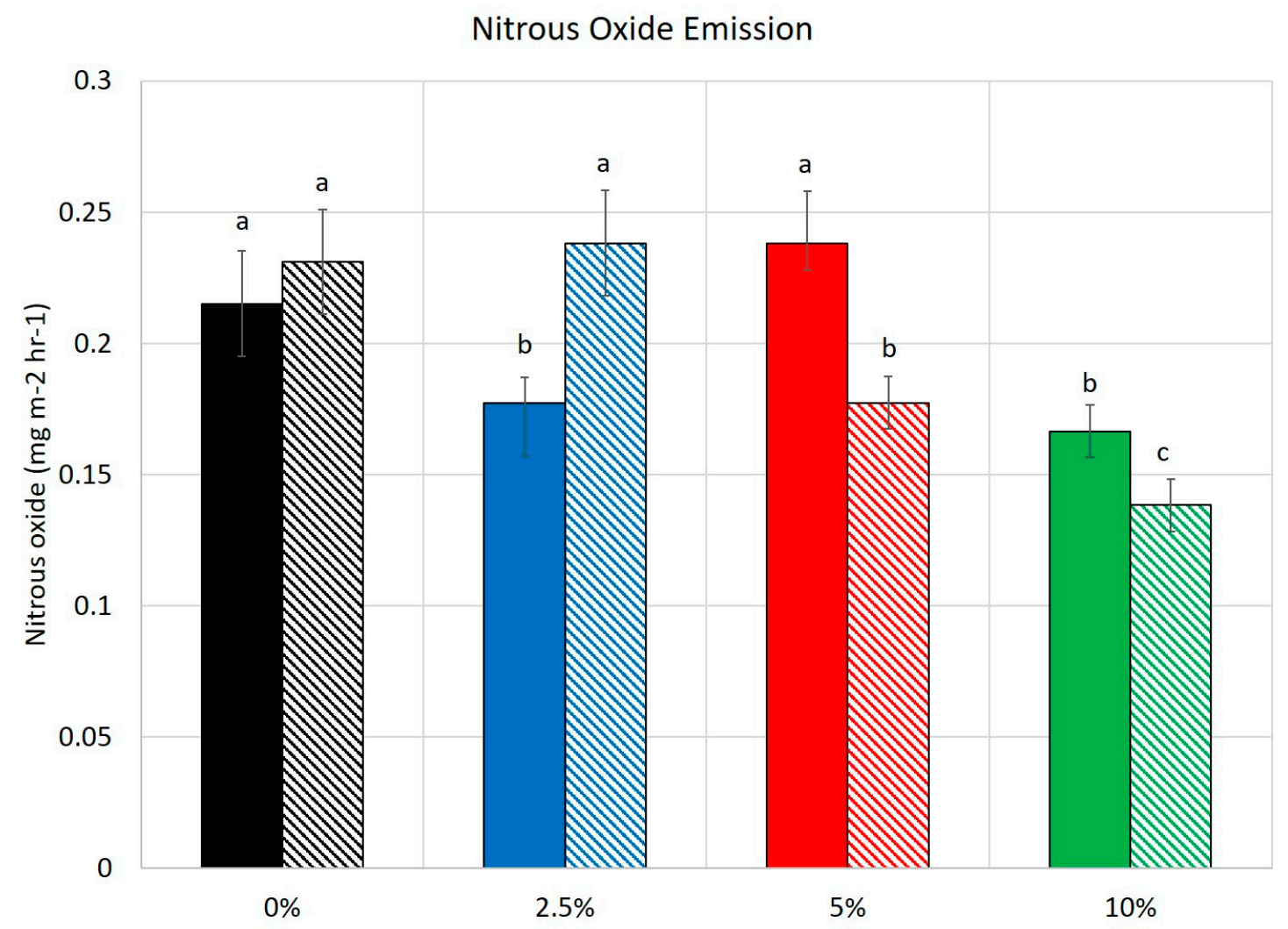

Figure 5. Nitrous oxide emission $\left(\mathrm{mg} \mathrm{m}^{-2} \mathrm{~h}^{-1}\right)$ over 42 days for bedded packs treated with $0,2.5,5$, and $10 \%$ alum either in one dose or in weekly doses. All treatments given in one dose are shown in solid colored bars and weekly increments are shown in striped bars for each treatment. Alum $\times$ Dose $p<0.01$.

\subsection{Hydrogen Sulfide}

Hydrogen sulfide flux was initially very low, peaked at Day 14 and then declined throughout the study (Figure 6). In a previous study, hydrogen sulfide was not measured directly, but total reduced sulfides peaked at Day 14, declined, and then began to increase again at 42 days [16]. In a second study, $\mathrm{H}_{2} \mathrm{~S}$ continued to increase until the end of the study, at Day 42 [14]. Both of the previous studies included wood products which produced a secondary peak of $\mathrm{H}_{2} \mathrm{~S}$, while the current study used only corn stover $[17,19]$. Sulfate-reducing bacteria are obligate anaerobes [40]. As the bedded packs aged, the material became more and more compacted, presumably creating an anaerobic environment under the surface of the bedded pack, which was conducive to the production of $\mathrm{H}_{2} \mathrm{~S}$. At peak $\mathrm{H}_{2} \mathrm{~S}$ flux, the bedded packs that were treated with $10 \%$ alum in one dose had a significantly higher $\mathrm{H}_{2} \mathrm{~S}$ flux than any other bedded packs. The bedded packs that received the $10 \%$ alum in weekly doses had a $\mathrm{H}_{2} \mathrm{~S}$ flux not different to the bedded packs that received the $5 \%$ or $2.5 \%$ alum in one dose. From Day 14 to Day 28, bedded packs that received $10 \%$ alum treatments had the highest $\mathrm{H}_{2} \mathrm{~S}$ flux, but overall $\mathrm{H}_{2} \mathrm{~S}$ flux decreased as the packs aged. The hydrogen sulfide flux from the bedded packs treated with weekly doses of $10 \%$ alum was $168 \%$ of the flux from untreated bedded packs. The increase in $\mathrm{H}_{2} \mathrm{~S}$ emission from bedded packs that received the $10 \%$ weekly alum dose could be related to two factors: increase in available sulfate due to the addition of sulfur as alum or a change in $\mathrm{pH}$. Bedded packs receiving $10 \%$ alum had the highest concentration of sulfur in the bedded pack material, and thus more available substrate for $\mathrm{H}_{2} \mathrm{~S}$ production. The release of gases from the bedded pack is also a function of the concentration of the gases near the surface in a non-ionized form, which can be easily affected by surface $\mathrm{pH}$. A reduction in $\mathrm{pH}$ typically favors the emission of weak acid forming gases, such as $\mathrm{CO}_{2}$ 
and $\mathrm{H}_{2} \mathrm{~S}$ [31]. While the $\mathrm{H}_{2} \mathrm{~S}$ flux did decrease over time, the higher flux observed when alum was used is a concern for producers using alum to control $\mathrm{NH}_{3}$ emissions, as $\mathrm{H}_{2} \mathrm{~S}$ emissions may increase.

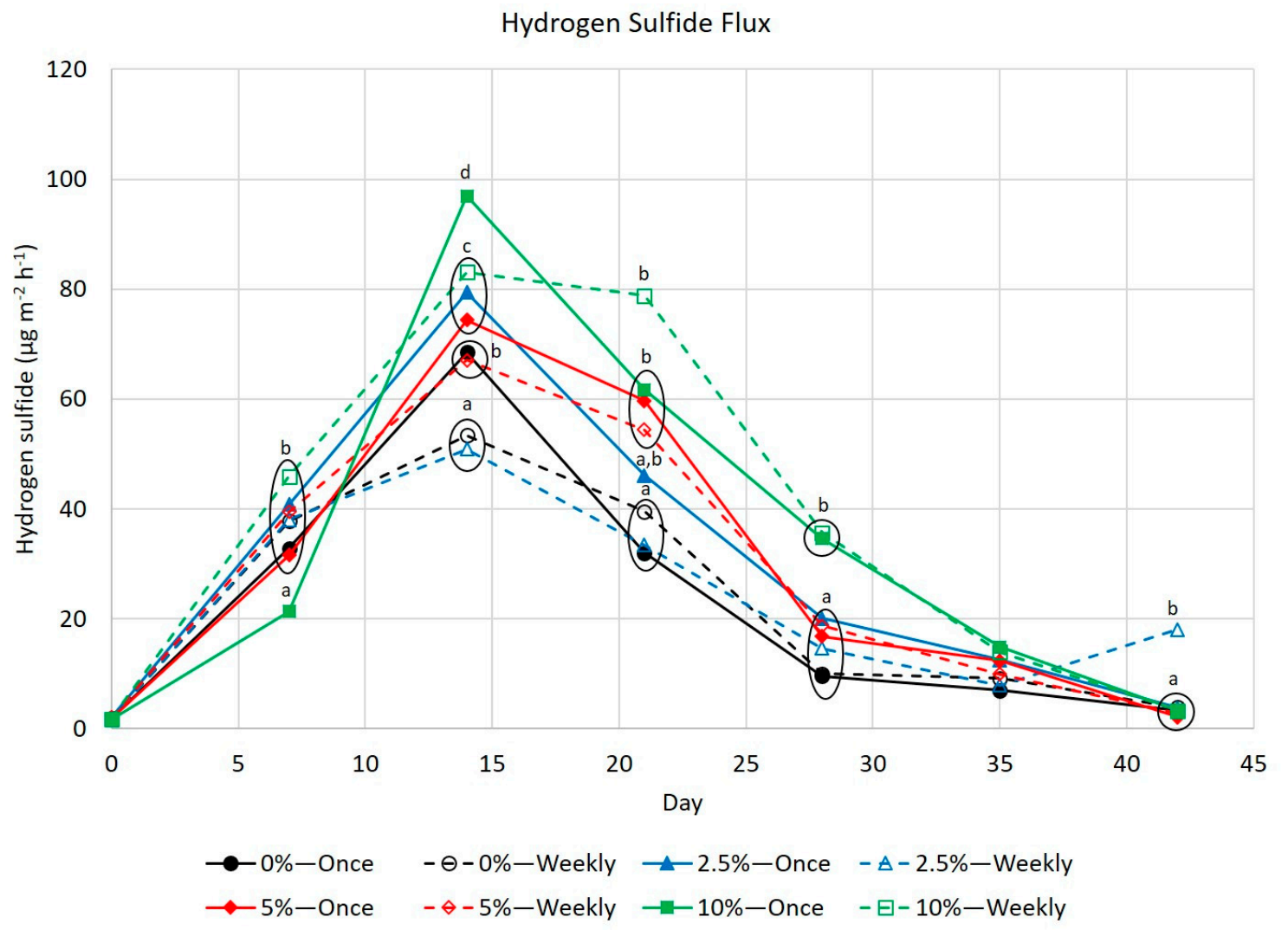

Figure 6. Average hydrogen sulfide flux $\left(\mu \mathrm{g} \mathrm{m}^{-2} \mathrm{~h}^{-1}\right)$ for weekly measurements taken over 42 days for bedded packs treated with $0,2.5,5$, and $10 \%$ alum either in one dose or in weekly doses. Alum $\times$ Dose $\times$ Day interaction $p<0.01$, pooled standard error of the mean $=4.62$. Clusters with different letters indicate significant differences $p<0.05$.

\subsection{Nutrient Composition}

The average dry matter content of the bedded packs at the end of the study was $22.7 \% \pm 1.3$, which was similar to the dry matter content of corn stover bedded packs in previous studies conducted similarly $[16,18,20]$ and slightly higher than the range of $16.9 \pm 0.45$ to $18.0 \pm 0.33$ measured over an 18-month period in commercial barns [23]. There was little difference in the nutrient composition of the bedded packs treated with the four concentrations of alum (Table 2). Because there were no interactions or differences due to the frequency of application, the table only includes nutrient concentrations for the main treatment effect of alum concentration. Phosphorus, potassium, and nitrogen content did not differ between all alum treatments. All bedded packs, regardless of treatment, had bedding, urine, and feces from a common source. Therefore, $\mathrm{N}$ input for all bedded packs was similar. With decreased $\mathrm{NH}_{3}$ emission, it was expected that the bedded packs treated with $10 \%$ alum would have a higher total $\mathrm{N}$ concentration than the untreated bedded packs, due to decreased $\mathrm{N}$ volatilization as ammonia. However, this was not the case. Either $\mathrm{N}$ was emitted in another form, such as $\mathrm{N}_{2}$ gas, that was not measured in this study, or $\mathrm{N}$ was retained in the pack but not detected using our analytical methods for total $\mathrm{N}$ detection. Perhaps some of the retained $\mathrm{N}$ was lost when the bedded pack material was dried prior to nutrient analysis. Another possibility for this anomaly is that the differences in cumulative $\mathrm{N}$ losses between the control and $10 \%$ alum treatments were small enough that they did not affect the total $\mathrm{N}$ concentration of the bedded pack materials. Sulfur increased with increasing levels of alum 
application. This was expected, as alum contains sulfur. This likely contributed to the increase in $\mathrm{H}_{2} \mathrm{~S}$ emissions from the bedded packs that received the $10 \%$ alum application.

Table 2. Average nutrient composition of the bedded packs at Day 42, following the addition of alum.

\begin{tabular}{ccccc}
\hline \multirow{2}{*}{ Alum } & Phosphorus & Potassium & Sulfur & Nitrogen \\
\cline { 2 - 5 } & \multicolumn{4}{c}{$\mathbf{g ~ k g}^{-\mathbf{1}} \mathbf{( D M )}$} \\
\hline $0 \%$ & 0.90 & 3.40 & 5.09 & 26.76 \\
$2.5 \%$ & 0.91 & 3.63 & 6.56 & 25.84 \\
$5 \%$ & 0.93 & 3.55 & 8.01 & 26.28 \\
$10 \%$ & 0.91 & 3.47 & 10.73 & 26.31 \\
\hline$p$-values & & & & \\
Alum & 0.9197 & 0.436 & $<0.01$ & 0.5036 \\
Frequency & 0.4274 & 0.5431 & 0.5338 & 0.8204 \\
Alum $\times$ Frequency & 0.4269 & 0.5966 & 0.6204 & 0.6662 \\
\hline
\end{tabular}

\section{Conclusions}

When alum was applied to a corn stover and manure mixture, it was necessary to use the $10 \%$ alum mixture to successfully lower $\mathrm{NH}_{3}$ emissions compared to the corn stover manure bedpack that was not treated with alum. A one-time dose of $10 \%$ alum was only able to sustain the lowered $\mathrm{NH}_{3}$ emissions for 14 days, but a total dose of $10 \%$ alum spread out in six equal weekly additions could maintain the reduced $\mathrm{NH}_{3}$ emissions for up to 42 days. Nitrous oxide emissions were also reduced when $10 \%$ alum was administered weekly. However, $\mathrm{CH}_{4}$ and $\mathrm{H}_{2} \mathrm{~S}$ emissions increased when the bedded packs were treated with $10 \%$ alum compared to bedded packs that did not receive an alum treatment. Producers need to be aware of the trade-offs of lowering one emission at the risk of increasing another and consider the benefits of lowering one emission relative to another. While effective, weekly additions of alum also present practical issues for livestock producers. It may be more effective to target areas of the pen most likely to emit $\mathrm{NH}_{3}$. Producers may also consider less frequent applications, such as once every two or three weeks, but additional research is needed to determine the efficacy of this approach.

Author Contributions: Conceptualization, M.J.S., B.L.W., D.B.P.; Methodology, M.J.S.; Software, M.J.S.; Validation, M.J.S.; Formal Analysis, M.J.S.; Investigation, M.J.S., B.L.W.; Data Curation, M.J.S.; Writing-Original Draft Preparation, M.J.S.; Writing-Review \& Editing, B.L.W., D.B.P.; Visualization, M.J.S..; Supervision, D.B.P.; Project Administration, M.J.S.; Funding Acquisition, M.J.S., B.L.W., D.B.P.

Funding: This project was funded by appropriated funds from the USDA. USDA is an equal opportunity provider and employer.

Acknowledgments: The author wishes to thank Alan Kruger, technician at USMARC, for help with data collection and lab analysis. The mention of trade names of commercial products in this article is solely for the purpose of providing specific information and does not imply recommendation or endorsement by the USDA.

Conflicts of Interest: The authors declare no conflict of interest.

\section{References}

1. Stowell, R. Ammonia loss and emission reporting: Considerations for cattle operations. UNL BeefWatch. 1 February 2018. Available online: http://newsroom.unl.edu/announce/beef/7498/42942 (accessed on 13 June 2018).

2. Todd, R.W.; Cole, N.A.; Clark, R.N.; Flesch, T.K. Ammonia emissions from a beef cattle feedyard on the Southern High Plains. Atmos. Environ. 2008, 42, 6797-6805. [CrossRef]

3. Bierman, S.; Erickson, G.E.; Klopfenstein, T.J.; Stock, R.A.; Shain, D.H. Evaluation of nitrogen and organic matter balance in the feedlot as affected by level and source of dietary fiber. J. Anim. Sci. 1999, 77, 1645-1653. [CrossRef] [PubMed] 
4. Erickson, G.E.; Milton, C.T.; Klopfenstein, T.J. Dietary protein effects on nitrogen excretion and volatilization in open-dirt feedlots. In Proceedings, Eighth International Symposium on Animal, Agricultural, and Food Processing Waste (ISAAF); American Society of Agricultural Engineers: St. Joseph, MI, USA, 2000.

5. Koelsch, R.; Erickson, G.; Homolka, M.; Luebbe, M. Predicting Manure Nitrogen, Phosphorus, and Carbon Characteristics of Open Lot Systems; ASABE Paper No. 1800946; ASABE: St. Joseph, MI, USA, 2018.

6. Bierman, S.; Klopfenstein, T.J.; Stock, R.; Shain, D. Evaluation of Nitrogen, Phosphorus, and Organic Matter Balance in the Feedlot as Affected by Nutrition; Beef Cattle Report MP66-A; University of Nebraska: Lincoln, NE, USA, 1996; pp. 74-76.

7. Van Horn, H.H.; Newton, G.L.; Kunkle, W.E. Ruminant nutrition from an environmental perspective: Factors affecting whole-farm nutrient balance. J. Anim. Sci. 1996, 74, 3082-3102. [CrossRef] [PubMed]

8. Hausinger, R.P. Metabolic versatility of prokaryotes for urea deposition. J. Bacteriol. 2004, 186, $2520-2522$. [CrossRef] [PubMed]

9. Hartung, J.; Phillips, V.R. Control of gaseous emissions from livestock buildings and manure stores. J. Agric. Eng. Res. 1994, 57, 173-189. [CrossRef]

10. Rhoades, M.B.; Parker, D.B.; Cole, N.A.; Todd, R.W.; Caraway, E.A.; Auvermann, B.W.; Topliff, D.R.; Schuster, G.L. Continuous ammonia emission measurements from a commercial beef feedyard in Texas. Trans. ASABE 2010, 53, 1823-1831. [CrossRef]

11. Moore, P.A., Jr.; Daniels, T.C.; Edwards, D.R. Reducing phosphorus runoff and inhibiting ammonia loss from poultry manure with aluminum sulfate. J. Environ. Qual. 2000, 29, 37-49. [CrossRef]

12. Moore, P.A.; Edwards, D.R. Long-term effects of poultry litter, alum-treated litter, and ammonium nitrate on phosphorus availability in soils. J. Environ. Qual. 2007, 36, 163-174. [CrossRef]

13. Moore, P.A., Jr.; Daniels, T.C.; Edwards, D.R. Reducing phosphorus and improving poultry production with alum. Poult. Sci. 1999, 78, 692-698. [CrossRef]

14. Sims, J.T.; Luka-McCafferty, N.J. On-farm evaluation of aluminum sulfate (alum) as a poultry litter amendment: Effects on litter properties. J. Environ. Qual. 2002, 31, 2066-2073. [CrossRef]

15. Penn, C.; Zhang, H. Alum-Treated Poultry Litter as a Fertilizer Source. Oklahoma Cooperative Extension Service PSS-2254. 2017. Available online: http://pods.dasnr.okstate.edu/docushare/dsweb/Get/Document5180/PSS-2254web13.pdf (accessed on 11 September 2019).

16. Spiehs, M.J.; Brown-Brandl, T.M.; Parker, D.B.; Miller, D.N.; Berry, E.D.; Wells, J.E. Effect of bedding materials on concentration of odorous compounds and Escherichia coli in beef cattle bedded manure packs. J. Environ. Qual. 2013, 42, 65-75. [CrossRef] [PubMed]

17. Spiehs, M.J.; Brown-Brandl, T.M.; Parker, D.B.; Miller, D.N.; Jaderborg, J.P.; DiCostanzo, A.; Berry, E.D.; Wells, J.E. Use of wood-based materials in beef bedded manure packs: 1. Effect on ammonia, total reduced sulfide, and greenhouse gas concentrations. J. Environ. Qual. 2014, 43, 1187-1194. [CrossRef] [PubMed]

18. Spiehs, M.J.; Brown-Brandl, T.M.; Berry, E.D.; Wells, J.E.; Parker, D.B.; Miller, D.N.; Jaderborg, J.P.; DiCostanzo, A. Use of wood-based materials in beef bedded manure packs: 2. Effect on odorous volatile organic compounds, odor activity value, Escherichia coli, and nutrient concentrations. J. Environ. Qual. 2014, 43, 1195-1206. [CrossRef] [PubMed]

19. Spiehs, M.J.; Brown-Brandl, T.M.; Parker, D.B.; Miller, D.N.; Berry, E.D.; Wells, J.E. Ammonia, total reduced sulfides, and greenhouse gases of pine chip and corn stover bedding packs. J. Environ. Qual. 2016, 45, 630-637. [CrossRef] [PubMed]

20. Spiehs, M.J.; Berry, E.D.; Wells, J.; Parker, D.B.; Brown-Brandl, T.M. Odorous volatile organic compounds, Escherichia coli, and nutrient composition when kiln-dried pine chips and corn stover bedding are used in beef bedded manure packs. J. Environ. Qual. 2017, 46, 722-732. [CrossRef] [PubMed]

21. Spiehs, M.J. Lab-scale model to evaluate odor and gas concentrations emitted by deep bedded pack manure. J. Vis. Exp. 2018, 137, e57332. [CrossRef]

22. Brown-Brandl, T.M.; Nienaber, J.A.; Eigenberg, R.A. Temperature and humidity control in indirect calorimeter chambers. Trans. ASABE 2011, 54, 685-692. [CrossRef]

23. Spiehs, M.J.; Woodbury, B.L.; Doran, B.E.; Eigenberg, R.A.; Kohl, K.D.; Varel, V.H.; Berry, E.D.; Wells, J. Environmental conditions in beef deep-bedded mono-slope facilities: A descriptive study. Trans. ASABE 2011, 54, 663-673. [CrossRef]

24. Miller, D.N.; Woodbury, B.L. A solid-phase microextraction chamber method for analysis of manure volatiles. J. Environ. Qual. 2006, 35, 2383-2394. [CrossRef] 
25. Woodbury, B.L.; Miller, D.N.; Eigenberg, R.A.; Nienaber, J.A. An inexpensive laboratory and field chamber for manure volatile gas flux analysis. Trans. ASABE 2006, 49, 767-772. [CrossRef]

26. Watson, M.; Wolf, A.; Wolf, N. Total nitrogen. In Recommended Methods of Manure Analysis; Publication No. A3769; University of Wisconsin Cooperative Extension: Madison, WI, USA, 2003; pp. 18-24.

27. Wolf, A.; Watson, M.; Wolf, N. Digestion and dissolution methods for $\mathrm{P}, \mathrm{K}, \mathrm{Ca}, \mathrm{Mg}$, and trace elements. In Recommended Methods of Manure Analysis; Publication No. A3769; University of Wisconsin Cooperative Extension: Madison, WI, USA, 2003; pp. 30-38.

28. Ayadi, F.Y.; Cortus, E.L.; Spiehs, M.J.; Miller, D.N.; Dijira, G.D. Ammonia and greenhouse gas concentration at surfaces of simulated beef cattle bedded manure packs. Trans. ASABE 2015, 58, 783-795.

29. Miller, D.N.; Varel, V.H. In vitro study of the biochemical origin and production limits of odorous compounds in cattle feedlots. J. Anim. Sci. 2001, 79, 2949-2956. [CrossRef] [PubMed]

30. Miller, D.N.; Varel, V.H. An in vitro study of manure composition on the biochemical origins, composition, and accumulation of odorous compounds in cattle feedlots. J. Anim. Sci. 2002, 80, 2214-2222. [CrossRef] [PubMed]

31. Dai, X.R.; Blanes-Vidal, V. Emissions of ammonia, carbon dioxide, and hydrogen sulfide from swine wastewater during and after acidification treatment: Effect of $\mathrm{pH}$, mixing, and aeration. J. Environ. Manag. 2013, 115, 147-154. [CrossRef] [PubMed]

32. Hellman, B.; Zelles, L.; Palojarvi, A.; Bai, Q. Emission of climate-relevant trace gases and succession of microbial communities during open-windrow composting. Appl. Environ. Microbiol. 1997, 63, 1011-1018.

33. Mackie, R.I.; Stroot, P.G.; Varel, V.H. Biochemical identification and biological origin of key odor components in livestock waste. J. Anim. Sci. 1998, 76, 1331-1342. [CrossRef]

34. Batstone, D.J.; Keller, J.; Angelidaki, I.; Kalyuzhnyi, S.V.; Pavlostathis, S.G.; Rozzi, A.; Sanders, W.T.M.; Siegrist, H.; Vavilin, V.A. The IWA anaertobic digestion model no. 1 (ADM1). Water Sci. Technol. 2002, 45, 65-73. [CrossRef]

35. Batstone, D.J.; Keller, J. Industrial applications of the IWA anaerobic digestions model no. 1 (ADM1). Water Sci. Technol. 2003, 47, 199-206. [CrossRef]

36. Arikan, O. Effect of temperature on methane production from field-scale anaerobic digesters treating dairy manure. In Waste to Worth: Spreading Science and Solutions; Livestock Poultry Environmental Learning Center: Seattle, WA, USA, 2015.

37. Chandra, R.; Takeuchi, H.; Hasegawa, T. Methane production from lignocellulosic agricultural crop wastes; A review in context to second generation of biofuel production. Renew. Sustain. Energy Rev. 2012, 16, 1462-1476. [CrossRef]

38. Tauseef, S.M.; Premalatha, M.; Abbasi, T.; Abbasi, S.A. Methane capture from livestock manure. J. Environ. Manag. 2013, 117, 187-207. [CrossRef]

39. Environmental Protection Agency. Inventory of U.S. Greenhouse Gas Emissions and Sinks 1990-2015. 2017. Available online: https://www.c2es.org/content/internation-emissions (accessed on 18 June 2018).

40. Reis, M.A.M.; Almeida, J.S.; Lemos, P.C.; Carrondo, M.J.T. Effect of hydrogen sulfide on growth of sulfate reducing bacteria. Biotechnol. Bioeng. 1992, 40, 593-600. [CrossRef] [PubMed]

(C) 2019 by the authors. Licensee MDPI, Basel, Switzerland. This article is an open access article distributed under the terms and conditions of the Creative Commons Attribution (CC BY) license (http://creativecommons.org/licenses/by/4.0/). 